\title{
Protective effects of Nigella sativa against hypertension-induced oxidative stress and cardiovascular dysfunction in rats
}

\author{
Nur Taşar1', Özer Şehirli1, Ömer Yiğiner², Selami Süleymanoğlu², Meral Yüksel³, \\ Berrak Yeğen ${ }^{4}$, Göksel Şener ${ }^{1}$
}

\begin{abstract}
We investigated the protective effect of Nigella sativa against oxidative injury in the heart and kidney tissues of rats with renovascular hypertension (RVH). RVH model was induced by placing a renal artery clip (2-kidney-1-clip, 2K1C) in Wistar albino rats $(n=8)$, while sham rats $(n=8)$ had no clip placement. Starting on the 3rd week after the operation, rats received Nigella sativa $(0.2 \mathrm{ml} / \mathrm{kg} / \mathrm{day}$, intraperitoneally) or vehicle for the following 6 weeks. Blood pressures (BP) were recorded at the beginning of the study and at the end of the 3rd and 9th weeks. Cardiac functions were assessed using transthoracic echocardiography before the rats were decapitated. Plasma samples were obtained to assay asymmetric dimethylarginine (ADMA), nitric oxide (NO), creatine kinase (CK) and lactate dehydrogenase (LDH) levels. Production of reactive oxidants was monitored by chemiluminescence (CL) assay in the cardiac and renal tissues. Moreover oxidative injury was examined through malondialdehyde (MDA) and glutathione (GSH) levels and $\mathrm{Na}+, \mathrm{K}+-\mathrm{ATPase}$ activity in these tissues. 2K1C caused increased BP and left ventricular (LV) dysfunction, while plasma ADMA, CK, and LDH levels were increased $(p<0.05-0.001)$. Moreover, hypertension caused significant decreases in plasma $\mathrm{NO}$ levels, as well as in tissue $\mathrm{Na}+, \mathrm{K}+-\mathrm{ATPase}$ activities and GSH contents, while MDA levels in both tissues were increased $(p<0.05-0.001)$. On the other hand, Nigella sativa treatment significantly reduced BP, attenuated oxidative injury and improved LV function. Nigella sativa protected against hypertension-induced tissue damage and improved cardiovascular function via its antioxidant and antihypertensive actions, suggesting a therapeutic potential of Nigella sativa in renovascular hypertension.
\end{abstract}

KEY WORDS: Antioxidant activity; hypertension; oxidative stress, Nigella sativa

\section{AFFILIATIONS \\ 'Marmara University School of Pharmacy, Department of Pharmacology, Istanbul, Türkiye \\ Gülhane Military Medical \\ Academy, Cardiology, \\ Istanbul, Türkiye \\ 3Marmara University, \\ Vocational School of \\ Health Related Professions, \\ Istanbul, Türkiye}

${ }^{4}$ Marmara University, School of Medicine, Department of

Physiology, Istanbul, Türkiye

CORRESPONDENCE

Nur Taşar

E-mail:

tasarn@yahoo.com

Received:

20.01.2012

Revision:

24.02.2012

Accepted:

24.02.2012

\section{INTRODUCTION}

Renovascular disease remains among the most prevalent and important causes of secondary hypertension and renal dysfunction. Hypertension develops in patients with renovascular disease from a complex set of pressor signals, including activation of the renin-angiotensin system, recruitment of oxidative stress pathways, and sympathoadrenergic activation (1). Activation of the renin-angiotensin system is the essential component of developing renovascular hypertension during the initial stages and plays an important role in the maintenance of hypertension, as well as in cardiac myocyte growth and oxidative stress (2). As an important component of the renin-angiotensin system, angiotensin II (Ang II) stimulates nicotinamide adenine dinucleotide phosphate $(\mathrm{NAD}(\mathrm{P}) \mathrm{H})$ oxidase enzyme, which can induce oxidative stress in the vasculature via generation of oxygen-free radicals (3). Experimental evidence also suggests that reactive oxygen species (ROS), which occur as a consequence of renal artery stenosis, enhance the hypertensive and hypertrophic responses to Ang II. Increased Ang II activity results in vasoconstriction, increased endothelin release, vascular remodeling, extracellular matrix deposition, and accelerated atherogenesis and glomerulosclerosis (4). These effects may contribute to the progression of cardiovascular and renal damage well beyond the effects of high blood pressure per se. 
It is well known that overproduction of ROS can lead to a damaging cycle of lipid peroxidation, depletion of natural antioxidants, perturbation of nitric oxide production, disruption of normal cellular metabolism and endothelial dysfunction (5). On the other hand, experimental blockade of the oxidative stress pathway with antioxidants in models of Goldblatt hypertension was shown to decrease renal injury and glomerulosclerosis, while renal hemodynamics was improved (6). Accordingly, free radical scavengers or antioxidants were proposed to be useful in hypertension-induced multi-organ damage. Recently, plant-based antioxidants used as dietary supplements were found to be effective for the management and prevention of hypertension and stress-related diseases due to their minimal side effects.

Nigella sativa L., commonly known as black seed, is a seed of capsulated plants, and belongs to the Ranunculacceae family. It is used in folk medicine as a natural remedy for a number of diseases and symptoms, such as asthma, hypertension, diabetes, inflammation, cough, bronchitis, headache, eczema, fever, dizziness and gastrointestinal disorders (7). Furthermore, thymoquinone (TQ), an active ingredient of the black seed oil from the plant Nigella sativa, has been shown to possess potent antioxidant properties (8). In our previous study we have demonstrated that Nigella sativa oil treatment reduced subarachnoid hemorrhage induced oxidative brain injury and associated neurological symptoms (9). Based on the above findings, in the present study we aimed to investigate the possible beneficial effects of Nigella sativa treatment on cardiovascular function and oxidative damage in rats with renovascular hypertension.

\section{MATERIALS AND METHODS Animals}

All experimental protocols were approved by the Marmara University (MU) Animal Care and Use Committee. Male Wistar albino rats (200-250 g), supplied by the MU Animal Center (DEHAMER), were kept at a constant temperature $\left(22 \pm 1^{\circ} \mathrm{C}\right)$ with $12 \mathrm{~h}$ light and dark cycles and fed a standard rat chow.

\section{Surgery and Experimental Design}

Two-kidney, one-clip (2K1C) has been studied as an Ang IIdependent model of renovascular hypertension with elevated circulating levels of Ang II and high Ang II concentration in the cortical tissue of the clipped and non-clipped kidneys (10). Clipping of the left renal artery and sham surgery were performed as previously described (10). Briefly, a silver clip (internal diameter $0.25 \mathrm{~mm}$ ) was placed around the left renal artery $(n=16)$ of the rats that were anesthetized with ketamine $(100 \mathrm{mg} / \mathrm{kg})$ and chlorpromazine $(0.75 \mathrm{mg} / \mathrm{kg})$ given intraperitoneally (ip). Half of the group with hypertension was treated with vehicle (corn oil, $1 \mathrm{ml} / \mathrm{kg} /$ day, ip), while the other half was treated with Nigella sativa oil (NS, at adose of 0.2 $\mathrm{ml} / \mathrm{kg} /$ day completed with corn oil to $1 \mathrm{ml} / \mathrm{kg}$ ) starting by the end of the $3^{\text {rd }}$ week after the clip-placement surgery and continued for the remaining 6 weeks. The rationale for the selected dose of NS depends on our previous reports demonstrating its protective action in other oxidative injury models (9). In the sham-operated control group $(n=8)$, animals had similar surgical procedures without clip-placement.

To obtain basal readings, systolic blood pressure recordings were obtained in all rats before the surgical procedures (clip placement or sham-operation), and these measurements were repeated at the end of the $3^{\text {rd }}$ and $9^{\text {th }}$ weeks after the surgery. All rats were decapitated following the $9^{\text {th }}$-week-measurements. Trunk blood was collected and immediately centrifuged at 3,000 $\mathrm{g}$ for $10 \mathrm{~min}$ to assay the plasma levels of lactate dehydrogenase $(\mathrm{LDH})$, creatine kinase $(\mathrm{CK})$, asymmetric dimethylarginine (ADMA), and nitric oxide (NO). Heart and kidney samples were taken for the determination of luminol and lucigenin chemiluminescence levels, malondialdehyde (MDA) and glutathione (GSH) levels and $\mathrm{Na}^{+}, \mathrm{K}^{+}$-ATPase activities.

\section{Measurement of Blood Pressure}

Indirect blood pressure measurement was made by the tail cuff method (Biopac MP35 Systems, Inc.) before the surgery and at the end of $3^{\text {rd }}$ and $9^{\text {th }}$ weeks following surgery. Initially, the rats were placed for $10 \mathrm{~min}$ in a chamber heated to $35^{\circ} \mathrm{C}$. Then the rats were placed in individual plastic restrainers and a cuff with a pneumatic pulse sensor was wrapped around their tails. Blood pressure recorded during each measurement period was averaged from at least three consecutive readings on that occasion obtained from each rat.

\section{Echocardiography}

Echocardiographic imaging and calculations were done according to the guidelines published by the American Society of Echocardiography (11) using a $12 \mathrm{MHz}$ linear transducer and 5-8 MHz sector transducer (Vivid 3, General Electric Medical Systems Ultrasound, Tirat Carmel, Israel). Under ketamine (50 mg/kg, i.p.) anesthesia, measurements were made from M-mode and two-dimensional images obtained in the parasternal long and short axes at the level of the papillary muscles after observation of at least 6 cardiac cycles. Interventricular septal thickness (IVS), left ventricular diameter (LVD) and left ventricular posterior wall thickness (LVPW) were measured during systole (s) and diastole (d). Ejection fraction (EF), fractional shortening (FS) and left ventricular mass (LVM) and relative wall thickness (RWT) were calculated from the M-mode images using the following formulas: \% $\mathrm{EF}=$ $\left[(\mathrm{LVDd})^{3}-(\mathrm{LVDs})^{3} /(\mathrm{LVDd})^{3} \times 100\right] ; \% \mathrm{FS}=[$ LVDd-LVDs $/$ LVDd X 100]; $L V M=\left[1.04 \times\left((L V D d+L V P W d+I V S d)^{3}-\right.\right.$ $\left.\left.(\mathrm{LVDd})^{3}\right) \times 0.8+0.14\right] ; \mathrm{RWT}=[2 \times(\mathrm{LVPWd} / \mathrm{LVDd})]$.

\section{Plasma assays}

Plasma levels of LDH and CK were determined spectrophotometrically using an automated analyzer (Bayer Opera biochemical analyzer, Germany), while ADMA concentration in plasma was measured with a highly sensitive ELISA kit (Immunodiagnostic AG, Bensheim, Germany). The intensity of the color reaction, measured by reading the optical density at $450 \mathrm{~nm}$ with a microtiter plate reader, is known to be inversely proportional with the amount of ADMA in the sample. NO metabolites (nitrates and nitrites) were assayed in plasma by the colorimetric method of Griess after enzymatic conversion of nitrates to nitrites by nitrate reductase using a colorimetric assay kit (Cayman Chemical, AnnArbor, MI, USA).

\section{Measurement of tissue luminol and lucigenin chemiluminescence}

To assess the contribution of ROS in renovascular hypertensioninduced tissue damage, luminol and lucigenin chemiluminescences (CL) were measured as indicators of radical formation. Lucigenin (bis-N-methylacridiniumnitrate) and luminol (5- 

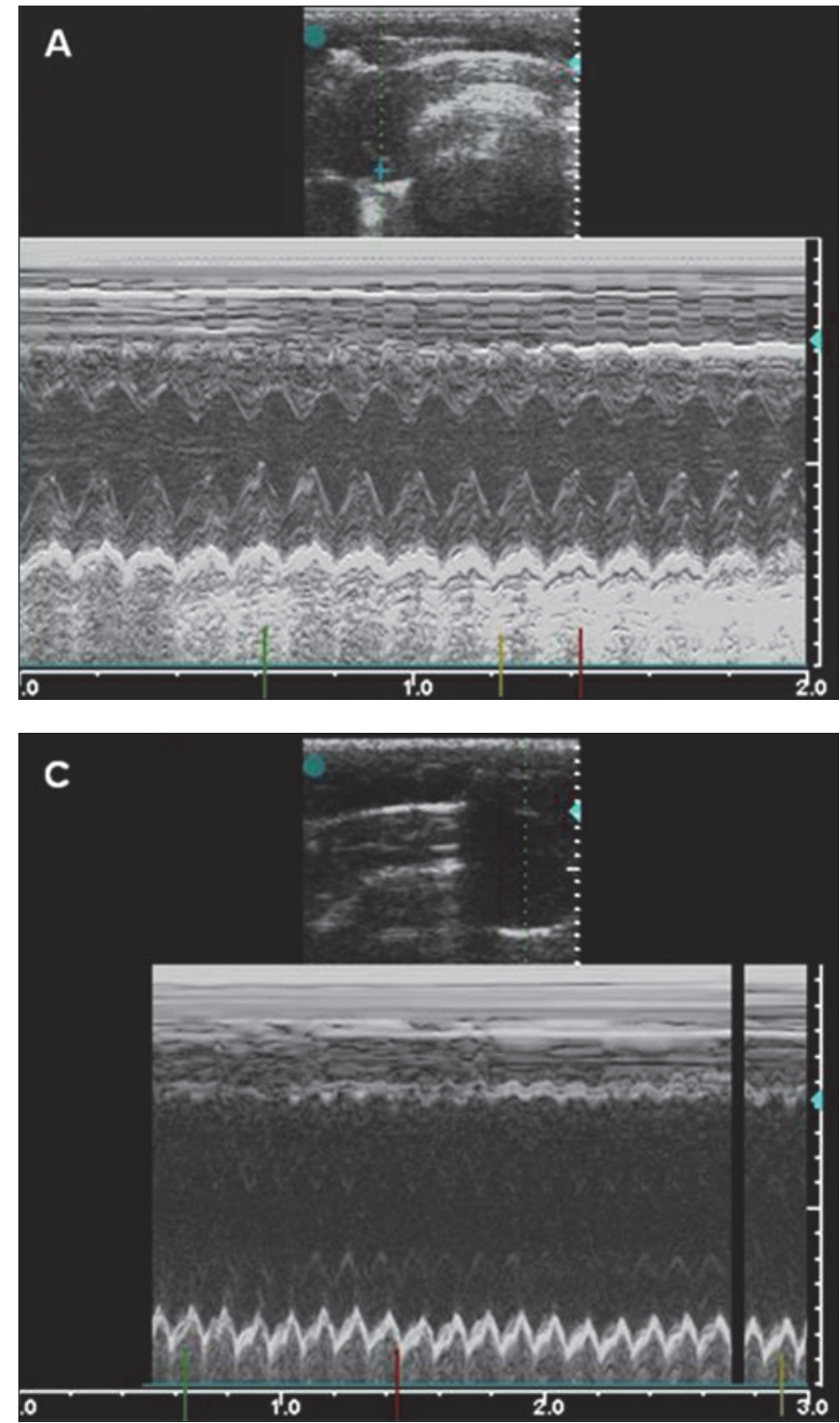

amino-2,3-dihydro-1,4-phthalazinedione) were obtained from Sigma (St Louis, MO). Measurements were made at room temperature using Junior LB 9509 luminometer (EG\&G Berthold, Germany). Specimens were put into vials containing PBSHEPES buffer (0.5 M PBS containing $20 \mathrm{mM}$ HEPES, pH 7.2). ROS were quantitated after the addition of enhancers such as lucigenin or luminol for a final concentration of $0.2 \mathrm{mM}$. Luminol detects a group of reactive species, i.e. $\mathrm{OH}, \mathrm{H}_{2} \mathrm{O}_{2}, \mathrm{HOCl}$ radicals and lucigenin is selective for $\mathrm{O}_{2}$ (12). Counts were obtained at $1 \mathrm{~min}$ intervals and the results were given as the area under curve (AUC) for a counting period of 5 minutes. Counts were corrected for wet tissue weight (rlu/mg tissue).

\section{Measurement of tissue malondialdehyde (MDA) and glutathione (GSH) levels}

Heart and kidney samples were homogenized with ice-cold $150 \mathrm{mM} \mathrm{KCl}$ for the determination of MDA and GSH levels. The MDA levels were assayed for products of lipid peroxidation by monitoring thiobarbituric acid reactive substance formation as described previously (13). Lipid peroxidation was expressed in terms of MDA equivalents using an extinction co-

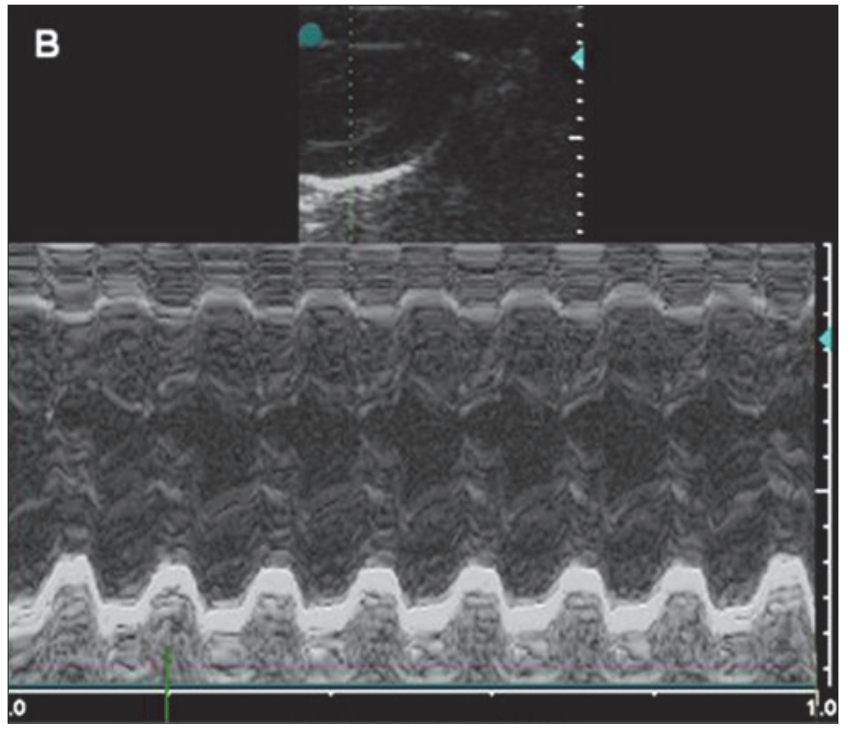

FIGURE 1. Representative echocardiographic scannings of control group with normal M-mode view (A); vehicle-treated RVH group with increased interventricular septum and left ventricular posterior wall thickness (B); NS-treated RVH group demonstrating normal M-mode view as the control group without hypertrophy $(\mathrm{C})$.

efficient of $1.56 \times 10^{5} \mathrm{M}^{-1} \mathrm{~cm}^{-1}$ and results are expressed as $\mathrm{nmol} \mathrm{MDA} / \mathrm{g}$ tissue. GSH measurements were performed using a modification of the Ellman procedure (14). Briefly, after centrifugation at $3000 \mathrm{rev} / \mathrm{min}$ for $10 \mathrm{~min}, 0.5 \mathrm{ml}$ of supernatant was added to $2 \mathrm{ml}$ of $0.3 \mathrm{~mol} / 1 \mathrm{Na}_{2} \mathrm{HPO}_{4} \cdot 2 \mathrm{H}_{2} \mathrm{O}$ solution. A $0.2 \mathrm{ml}$ solution of dithiobisnitrobenzoate $(0.4 \mathrm{mg} / \mathrm{ml} 1 \%$ sodium citrate) was added and the absorbance at $412 \mathrm{~nm}$ was measured immediately after mixing. GSH levels were calculated using an extinction coefficient of $1.36 \times 10^{4} \mathrm{M}^{-1} \mathrm{~cm}^{-1}$. Results are expressed in $\mu \mathrm{mol} \mathrm{GSH} / g$ tissue.

\section{Measurement of $\mathrm{Na}+, \mathrm{K}+-$ ATPase activity}

The activity of $\mathrm{Na}^{+}, \mathrm{K}^{+}$-ATPase, a membrane-bound enzyme required for cellular transport, is very sensitive to free radical reactions and lipid peroxidation. Accordingly, a reduction in $\mathrm{Na}^{+}, \mathrm{K}^{+}$-ATPase activity indirectly indicates membrane damage. Measurement of $\mathrm{Na}^{+}, \mathrm{K}^{+}$-ATPase activity is based on the measurement of inorganic phosphate released by ATP hydrolysis during incubation of homogenates with an appropriate medium. The total ATPase activity was determined in the presence of $100 \mathrm{mM} \mathrm{NaCl}, 5 \mathrm{mM} \mathrm{KCl}, 6 \mathrm{mM} \mathrm{MgCl}, 0.1 \mathrm{mM}$ EDTA, $30 \mathrm{mM}$ Tris $\mathrm{HCl}$ (pH 7.4), while the $\mathrm{Mg}^{2+}$-ATPase activity was determined in the presence of $1 \mathrm{mM}$ ouabain. The difference between the total and the $\mathrm{Mg}^{2+}$-ATPase activities was taken as a measure of the $\mathrm{Na}^{+}, \mathrm{K}^{+}$-ATPase activity (15). The reaction was initiated with the addition of the homogenate $(0.1$ $\mathrm{ml}$ ) and a 5 -min pre-incubation period at $37^{\circ} \mathrm{C}$ was allowed. Following the addition of $3 \mathrm{mM} \mathrm{Na}_{2} \mathrm{ATP}$ and a 10 -min re-incubation period, the reaction was terminated by the addition of ice-cold $6 \%$ perchloric acid. The mixture was then centrifuged at $3500 \mathrm{~g}$, and Pi in the supernatant fraction was determined by the method of Fiske and Subarrow (16). The specific activity of the enzyme was expressed as micronmol $\mathrm{Pi} \mathrm{mg}^{-1}$ protein $\mathrm{h}^{-1}$. The protein concentration of the supernatant was measured by the Lowry method (17). 
TABLE 1. Systolic blood pressures (BP) recorded before the surgical procedure (t1) and at the 3rd (t2) and 9th (t3) weeks after the surgery in the sham-operated control, Nigella sativa (NS)-treated control, vehicle-treated renovascular hypertension (RVH) and NS-treated RVH (RVH+NS) groups. Each group consists of 8 animals.

\begin{tabular}{ccccc}
\hline $\begin{array}{c}\text { BP } \\
(\mathbf{m m H g})\end{array}$ & Control & NS & RVH & RVH+NS \\
\hline$t_{1}$ & $121 \pm 1.9$ & $118 \pm 1.9$ & $116 \pm 2.0$ & $117 \pm 1.9$ \\
$t_{2}$ & $122 \pm 2.1$ & $119 \pm 2.0$ & $156 \pm 3.2^{* *}$, \&\&\& & $145 \pm 2.4^{* * *}, \& \& \&$ \\
$t_{3}$ & $125 \pm 2.2$ & $121 \pm 2.1$ & $185 \pm 4.8^{* * *}, \& \& \&$ & $151 \pm 3.6^{* * *}, \& \& \&,+++$ \\
\hline
\end{tabular}

Data are expressed as mean \pm SEM. ${ }^{* * *} p<0.001$ vs $t_{1}$ value ; ${ }^{+++} p<0.001$ vs RVH group; \&\&\& $p<0.001$ vs control group.

TABLE 2. Transthoracic echocardiographic measurements recorded at the 9th week in the sham-operated control, Nigella sativa (NS)-treated control, vehicletreated renovascular hypertension (RVH) and NS-treated RVH (RVH+NS) groups. Each group consists of 8 animals.

\begin{tabular}{|c|c|c|c|c|}
\hline & Control & NS & RVH & $\mathrm{RVH}+\mathrm{NS}$ \\
\hline IVS (mm) & $2.10 \pm 0.06$ & $2.45 \pm 0.11$ & $3.03 \pm 0.12^{\star \star *}$ & $2.51 \pm 0.17+$ \\
\hline PW (mm) & $1.84 \pm 0.06$ & $1.86 \pm 0.07$ & $2.54 \pm 0.09 * \star \star$ & $2.18 \pm 0.13^{+}$ \\
\hline RWT & $0.63 \pm 0.02$ & $0.65 \pm 0.03$ & $1.10 \pm 0.07^{\star \star *}$ & $0.81 \pm 0.09+$ \\
\hline LVDs (mm) & $2.71 \pm 0.22$ & $2.76 \pm 0.21$ & $4.45 \pm 0.17 * \star \star$ & $3.43 \pm 0.25+$ \\
\hline LVDd (mm) & $4.22 \pm 0.11$ & $4.07 \pm 0.11$ & $5.48 \pm 0.15^{\star \star \star}$ & $4.77 \pm 0.18^{*},++$ \\
\hline EF (\%) & $79.7 \pm 2.7$ & $77.5 \pm 3.4$ & $59.8 \pm 3.1$ ** & $74.7 \pm 4.1+$ \\
\hline FS (\%) & $42.4 \pm 3.4$ & $41.3 \pm 2.7$ & $24.5 \pm 1.7^{\star \star \star}$ & $36.3 \pm 2.9+$ \\
\hline
\end{tabular}

IVS: interventricular septal thickness (IVS); PW: left ventricular posterior wall thickness; RWT: relative wall thickness; LVDs: left ventricular diameter in systole; LVDd: left ventricular diameter in diastole; EF: ejection fraction; FS: fractional shortening. ${ }^{*} p<0.05,{ }^{* *} p<0.01,{ }^{* * *} p<0.001$ compared with control group ${ }^{+} p<0.05,{ }^{++} p<0.01$ compared with RVH group.

A

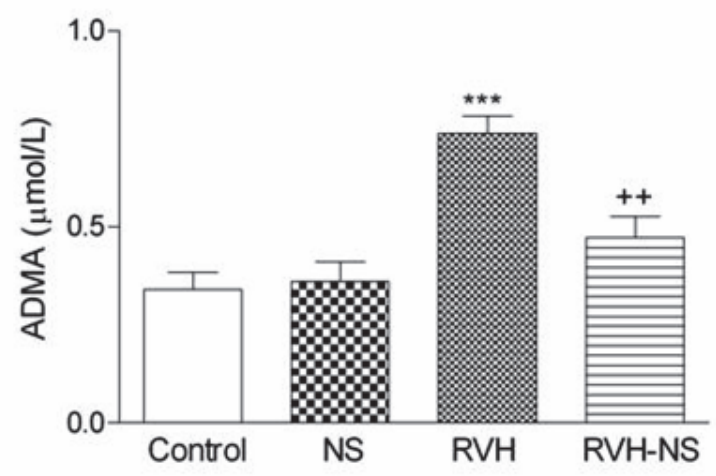

C

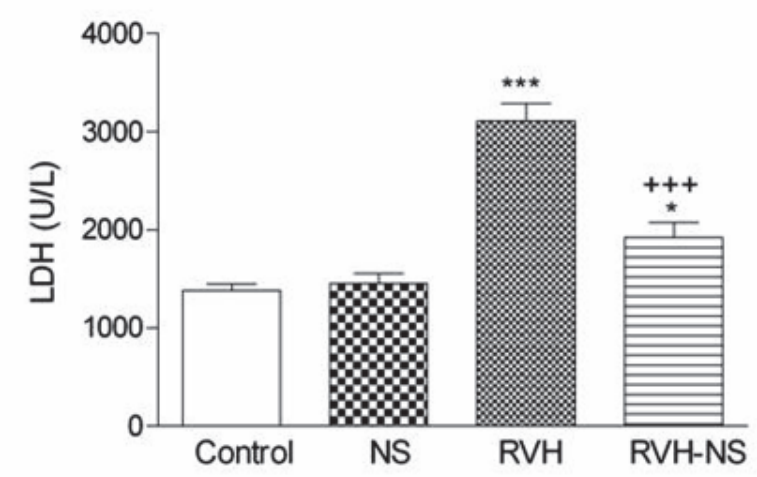

$\mathbf{B}$

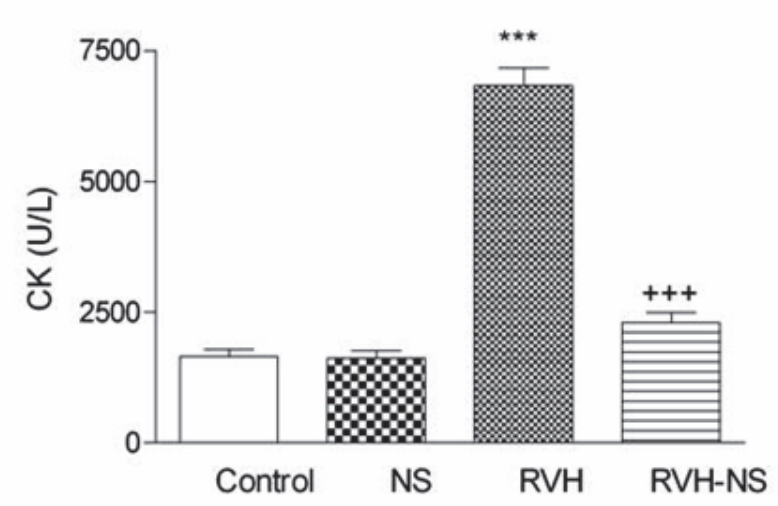

D

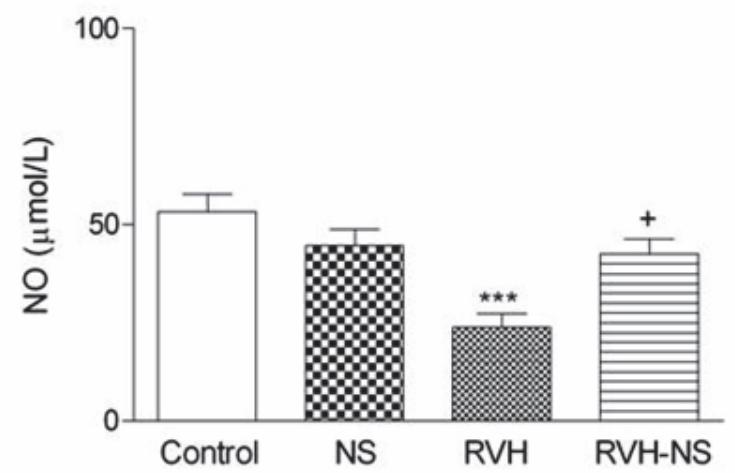

FIGURE 2. Plasma levels of ( $A$ ) asymmetric dimethylarginine (ADMA), (B) nitric oxide (NO) metabolites, (C) creatinine kinase (CK) and d) lactate dehydrogenase (LDH) in the sham-operated control, Nigella sativa (NS)-treated control, vehicle-treated renovascular hypertension (RVH) and NS-treated RVH groups (RVH+NS). *** $p<0.001$; compared to control, $+p<0.05,++p<0.01$; compared to RVH group. 


\section{Statistics}

Statistical analysis was carried out using GraphPad Prism 3.0 (GraphPad Software, San Diego; CA; USA). Each group consisted of 8 animals. All data were expressed as means \pm SEM. Groups of data were compared with an analysis of variance (ANOVA) followed by Tukey's multiple comparison tests. Values of $\mathrm{p}<0.05$ were regarded as significant.

\section{RESULTS}

\section{Blood pressure and echocardiograpic measurements}

As shown in Table 1, in the vehicle-treated RVH group the mean systolic blood pressures were significantly elevated at the $3^{\text {rd }}(156 \pm 3.2 \mathrm{mmHg} ; \mathrm{p}<0.001)$ and $9^{\text {th }}(185 \pm 4.8 \mathrm{mmHg}$; $\mathrm{p}<0.001)$ weeks with respect to the basal values. In the NStreated RVH group, at the $3^{\text {rd }}$ week where treatment was not started yet, mean BP was still elevated $(145 \pm 2.4 \mathrm{mmHg}$; $\mathrm{p}<0.001)$, while at the $9^{\text {th }}$ weeks BP was significantly reduced $(151 \pm 3.6 \mathrm{mmHg})$ with respect to vehicle-treated $\mathrm{RVH}$ group $(\mathrm{p}<0.001)$.

Table 2 summarizes the transthoracic echocardiographic measurements of the experimental groups recorded at the $9^{\text {th }}$ week. As compared to the control values, in the vehicle-treated $\mathrm{RVH}$ group, interventricular septal thickness, LV posterior wall thickness, LV end-diastolic and end-systolic dimensions, as well as relative wall thickness, were increased $(p<0.001)$, while percent fractional shortening and ejection fraction were decreased $(p<0.01-0.001$; Figure 1). On the other hand, in the NS-treated RVH group echocardiographic measurements were significantly reversed and the values were found to be similar to those of the control group.

\section{Biochemical parameters in the plasma}

Plasma ADMA, CK and LDH levels were significantly elevated in the vehicle-treated RVH group $(p<0.001)$, while NO metabolites were decreased (Figure 2). On the other hand, NStreatment decreased the plasma ADMA, CK and LDH levels, while NO metabolites were significantly increased $(p<0.05-$ 0.001).

\section{Biochemical parameters in the tissues}

Luminol and lucigenin CL levels indicating oxygen radical generation were increased in the cardiac and renal tissues of the vehicle-treated $\mathrm{RVH}$ group as compared to those of the corresponding tissues from the control group $(p<0.001$, Table $3)$. However, in the NS-treated RVH group, elevations in both of the CL levels were abolished $(\mathrm{p}<0.01-0.01)$. In accordance with these results, the levels of MDA, which is a major degradation product of lipid peroxidation, were significantly increased $(p<0.001)$ in the heart and kidney tissues of the vehicle treated-RVH group, while GSH levels were decreased in both tissues $(\mathrm{p}<0.001)$ as compared to the control group (Figure 3 and 4). On the other hand, NS treatment given to the hypertensive rats caused marked decreases in the MDA levels of both tissues $(p<0.01)$ and increases in the GSH levels. Furthermore, $\mathrm{RVH}$-induced oxidative stress caused significant decreases in the $\mathrm{Na}^{+}, \mathrm{K}^{+}$-ATPase activities of the cardiac and renal tissues when compared to those of the control group $(p<0.001)$, indicating impaired transport function and membrane damage in both tissues (Figure $3 \mathrm{c}$ and $4 \mathrm{c}$ ). On the other hand, 2K1C-induced reductions in tissue $\mathrm{Na}^{+}, \mathrm{K}^{+}$-ATPase activities were prevented with NS treatment in the RVH group $(\mathrm{p}<0.05)$.
A

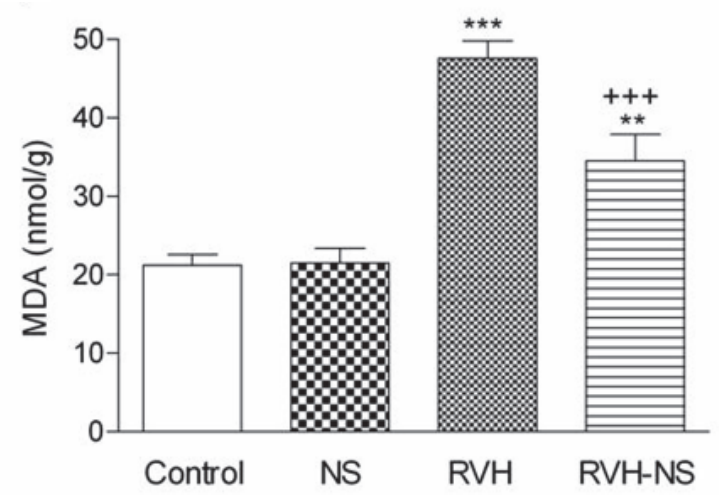

B

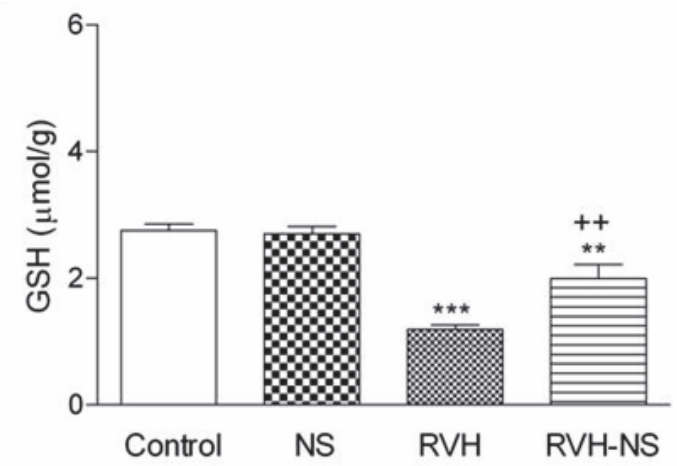

C

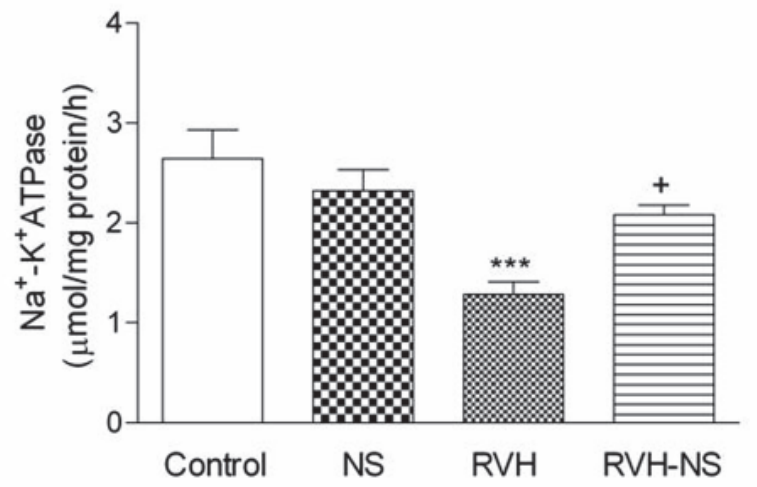

FIGURE 3. Malondialdehyde (MDA) levels (A), glutathione levels (B) and $\mathrm{Na}+$ $\mathrm{K}+$ ATPase activities (C) in the heart tissues of the sham-operated control, Nigella sativa (NS)-treated control, vehicle-treated renovascular hypertension (RVH) and NS-treated RVH groups (RVH+NS). ${ }^{*} p<0.05,{ }^{* \star} p<0.01$, ${ }^{* \star *} p<0.001$; compared to control, $++p<0.01,+++p<0.001$; compared to RVH group.

\section{DISCUSSION}

In the present study, elevated systolic blood pressure and cardiac dysfunction induced by clip placement were reduced significantly when the animals were treated with NS. The treatment with NS also prevented the severity of hypertension-induced oxidative stress: elevations in plasma ADMA, CK, and LDH levels with 
A

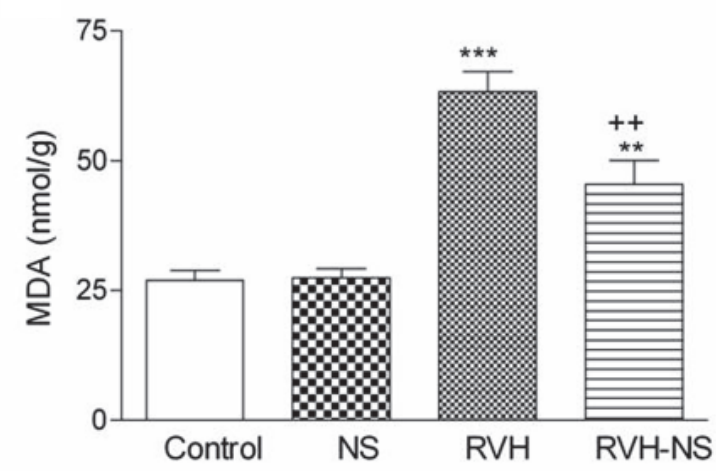

B

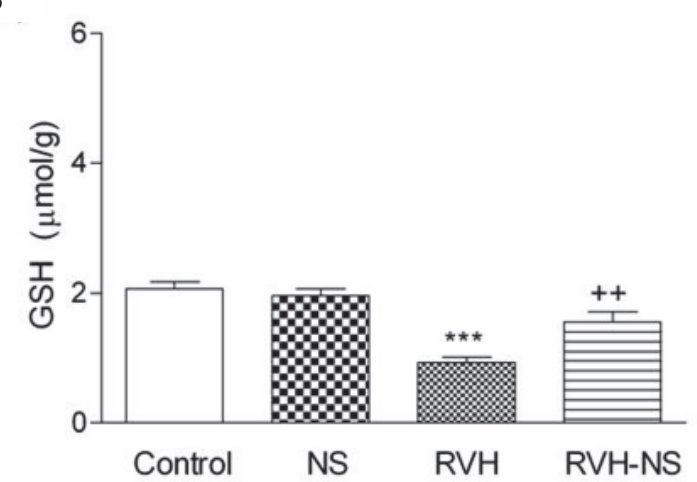

C

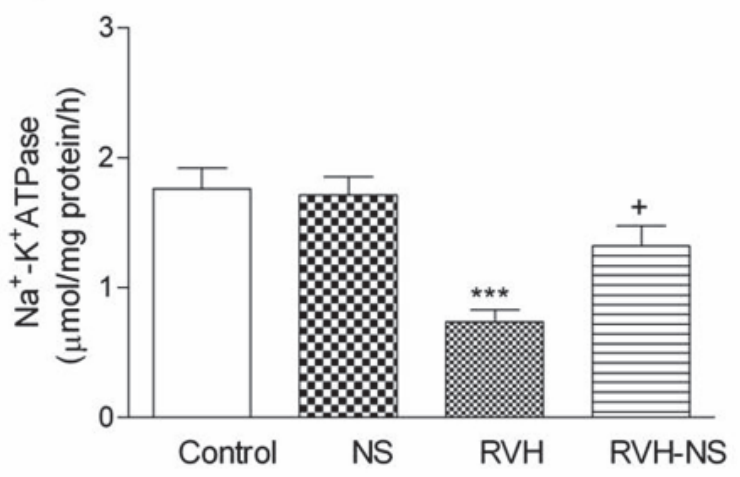

FIGURE 4. Malondialdehyde (MDA) levels (A), glutathione levels (B) and $\mathrm{Na}+, \mathrm{K}+$-ATPase activities (C) in the kidney tissues of the sham-operated control, Nigella sativa (NS)-treated control, vehicle-treated renovascular hypertension $(\mathrm{RVH})$ and NS-treated RVH groups (RVH+NS). ${ }^{*} \mathrm{p}<0.05,{ }^{* *} \mathrm{p}<0.01,{ }^{* * *} \mathrm{p}<0.001$; compared to control, $++p<0.01,+++p<0.001$; compared to $\mathrm{RVH}$ group.

a concomitant reduction in NO levels, as well as MDA and CL levels along with reduced GSH and $\mathrm{Na}^{+}, \mathrm{K}^{+}$-ATPase activity in the cardiac and renal tissue were reversed by NS treatment.

It is well known that $\mathrm{NO}$, which is synthesized from L-arginine by NO synthase, is one of the regulators of vascular tone. There is a growing body of clinical evidence to support the hypothesis that NO/ asymmetrical dimethylarginine (ADMA) pathway is important for the pathogenesis of cardiovascular diseases. It has been demonstrated that in several human diseases, there is an increase in serum levels of methylated 1-arginines, such as ADMA, which is a competitive inhibitor of nitric oxide synthase and may decrease NO availability (18). ADMA is shown to be accumulated in various disease states, including renal failure, diabetes mellitus, hyperhomocysteinemia and pulmonary hypertension, and its concentration in plasma is strongly predictive of premature cardiovascular disease and death (19). In an attempt to associate the ADMA/NO availability with the effects of NS on RVH pathogenesis, we have studied plasma ADMA levels and found that in the rats with RVH its levels were significantly higher than normotensive controls indicating decreased bioavailability of NO. Indeed plasma NO levels were found to be reduced. Furthermore, in rats with RVH, plasma CK and LDH levels were also found to be increased, which suggest generalized tissue damage associated with enhanced ROS generation, verified by CL data. Although it is difficult to quantitate oxygen radicals because of their reactive nature and short lives, CL is a simple but a reproducible technique. The two CL probes, luminol and lucigenin, differ in selectivity. Luminol detects $\mathrm{H}_{2} \mathrm{O}_{2}, \mathrm{OH}-$, hypochlorite, peroxynitrite, and lipid peroxyl radicals, whereas lucigenin is particularly sensitive to superoxide radical (12). In the present study, increased luminol ve lucigenin CL levels indicate RVH-induced ROS generation and support the decreased NO bioavailability, which may be due to accumulated ADMA levels. However, in the present study, the NS treatment with its well-known antioxidant effects has reduced the generation of ROS. More specifically, it also appears that reduction in superoxide radical with NS treatment may have increased the bioavailability of NO, which may be responsible for the normalization of blood pressure in the NS-treated rats.

Under pathological conditions, increased ROS bioactivity leads to endothelial dysfunction, increased contractility, vascular smooth muscle cell (VSMC) growth, monocyte invasion, lipid peroxidation, inflammation, and increased deposition of extracellular matrix proteins, important factors in hypertensive vascular damage (20). Increased vascular $\mathrm{O}_{2}^{-\bullet}$ production in Ang II-induced hypertension was shown to reduce the biological activity of endothelium-derived NO. In accordance with enhanced ROS generation, in the present $2 \mathrm{~K} 1 \mathrm{C}$ model, MDA levels in the kidneys and cardiac tissues were also increased significantly, implicating the presence of enhanced lipid peroxidation and indicating that oxidative stress generated in the kidneys contributes to the generation and maintenance of hypertension. Similarly, decreased activity of $\mathrm{Na}^{+}, \mathrm{K}^{+}-$ ATPase, which is a membrane-bound enzyme that requires phospholipids for its activity, also indicates lipid peroxidation-induced injury in the studied tissues (21). The potential harmful effects of ROS are controlled by a cellular antioxidant defense mechanism, including enzymatic defense systems and non-enzymatic defense systems such as GSH (22). Experimental and clinical studies support the hypothesis that development of hypertension and hypertension-induced damage in target organs are associated with oxidative stress and inflammation $(23,24)$. On the other hand, blockade of the oxidative stress was shown to improve tissue blood perfusion and prevent inflammation in the affected organ (25). In the present study, NS treatment reduced the elevated levels of MDA and 
TABLE 3. Effects of Nigella sativa (NS) treatment on tissue luminol and lucigenin chemiluminescence (CL; rlu/mg) levels in the sham-operated control, NS-treated control, vehicle-treated renovascular hypertension $(\mathrm{RVH})$ and NS-treated $\mathrm{RVH}(\mathrm{RVH}+\mathrm{NS})$ groups. Each group consists of 8 animals.

\begin{tabular}{|c|c|c|c|c|}
\hline & Control & NS & RVH & RVH+NS \\
\hline \multicolumn{5}{|c|}{ Luminol CL } \\
\hline Heart & $11.03 \pm 0.81$ & $16.09 \pm 1.93$ & $43.20 \pm 6.40^{\star \star \star}$ & $21.47 \pm 2.51++$ \\
\hline Kidney & $11.40 \pm 1.33$ & $14.64 \pm 1.94$ & $11.74 \pm 12.13^{\star \star \star}$ & $26.38 \pm 4.73^{+++}$ \\
\hline \multicolumn{5}{|c|}{ Lucigenin CL } \\
\hline Heart & $10.82 \pm 0.58$ & $11.23 \pm 1.08$ & $48.59 \pm 4.98 * * *$ & $22.09 \pm 3.75^{+++}$ \\
\hline Kidney & $10.22 \pm 1.28$ & $10.65 \pm 0.81$ & $50.97 \pm 8.40^{* * *}$ & $20.08 \pm 2.30+++$ \\
\hline
\end{tabular}

$\mathrm{Na}^{+}, \mathrm{K}^{+}$-ATPase activities in both the kidney and heart, showing the reduction in lipid peroxidation. Accordingly, GSH levels in both tissues and plasma NO levels were also increased by NS treatment verifying its powerful antioxidant effect, which had been shown in many situations associated with oxidative stress. In a study with streptozotocin-induced diabetic rats, NS treatment has significantly decreased pancreatic tissue MDA levels, while antioxidant superoxide levels were increased (26). Similarly, El-Abhar et al (27). have shown that increased gastric tissue MDA levels, induced by ischemia/ reperfusion of celiac artery, were reduced by both NS and TQ treatments. The compound TQ shares structural homology with coenzyme $Q$, which is an important antioxidant in the electron transport chain, and both NS as well as TQ have been shown to inhibit lipid peroxidation (28) and alleviate NO-induced hypertension in rats (29). Ismail et al (30). have demonstrated that TQ-rich fraction extracted from NS and its bioactive compound, TQ, effectively improved the plasma and liver antioxidant capacity and enhanced the expression of liver antioxidant genes in the hypercholesterolemic rats. We have recently shown in an experimental subarachnoid hemorrhage model that administration of NS decreased MDA levels in the brain tissue of rats, while depleted antioxidant GSH levels were restored (9). Thus, in accordance with the aforementioned findings, the current study also demonstrates that NS displays significant beneficial actions against oxidative cellular toxicity in the 2K1C-hypertension model.

Hypertension has been considered as the main cause of left ventricular hypertrophy $(\mathrm{LVH})$ for a long time. The presence of $\mathrm{LVH}$ in hypertension is associated with an increased risk of mortality and morbidity several times above and beyond the risk of hypertension alone. The pathogenesis of $\mathrm{LVH}$ is multifactorial. Although directly related to systolic blood pressure, other factors including age, sex, race, stimulation of the renin-angiotensin-aldosterone and sympathetic nervous systems, body mass index and endothelial dysfunction play an important role in the pathogenesis of LVH (18). It has been suggested that local up-regulation of Ang-II production and activity play a key role in the induction of left LVH (31). In agreement with these studies, our echocardiographic measurements obtained at the end of the $9^{\text {th }}$ week from 2K1C-hypertensive rats showed the presence of left ventricular dysfunction, while the observed oxidative changes suggested that they may be responsible for the resultant LV dysfunction. On the other hand, NS treatment through its antioxidant properties decreased the ADMA and increased NO levels in plasma hence decreased blood pressure, depressed hypercontractility and improved cardiac functions, further implying the role of oxidative mechanisms on the development and maintenance of LV dysfunction.

As supported with the present data, experimental evidence supports the hypothesis that hypertension-enhanced oxidative stress may be related to the activation of the renin-angiotensin system (2). In patients with hypertension and renovascular disease, the pro-oxidant effects of Ang-II may amplify long-standing hypertension. It is well known that hypertension is a lifestyle-related disease and dietary modifications are effective for its management and prevention. Based on experimental evidence where oxidative stress may take a place in multiorgan damage, there has been great interest in developing strategies that target ROS. Thus, among several therapeutic approaches that have been considered to increase antioxidant bioavailability or to reduce ROS generation in hypertension, in the present study, we investigated the possible protective impact of Nigella sativa, an annual flowering plant, against hypertension-induced cardiac and renal damage. In conclusion, present results further verify that involvement of oxidative stress is critical in the development and maintenance of renovascular hypertension, and suggest a therapeutic role for Nigella sativa in preserving the target organs against hypertension-induced oxidative damage and in improving cardiovascular function.

Declaration of interest: The study was supported by Marmara University Scientific Research Projects Commission (SAG-CYLP-270109-0014). The authors report no conflicts of interest. The authors alone are responsible for the content and writing of the paper. 


\section{Nigella sativa'nın sıçanlarda hipertansiyon ile oluşan oksidan hasara ve kardiyak disfonksiyona karşı koruyucu etkileri}

ÖZET: Bu çalışmada Nigella sativa'nın sıçanlarda renovasküler hipertansiyonun (RVH) neden olduğu kalp ve böbrek dokularındaki oksidan hasara karşı koruyucu etkileri incelendi. RVH Wistar albino sıçanların sol böbrek arterine yerleştirilen klip ile oluşturulurken (iki böbrek tek klip modeli; $2 B 1 K, n=8)$ taklit grubu sıçanlarda $(n=8)$ klip yerleştirmeksizin cerrahi uygulandı. Cerrahi işlemin 3.haftasından başlayarak 6 hafta süresince sıçanlara Nigella sativa $(0.2$ $\mathrm{mg} / \mathrm{kg} / \mathrm{gün}$, intraperitoneal) veya taşıyıcı uygulamaları yapıldı. Çalışmanın başlangıcında, 3.haftada ve 9.haftada kan basıncı (KB) öllçümleri alınırken dekapitasyondan önce tüm hayvanların transtorasik ekokardiografik görüntüleri kaydedildi. Plazma örneklerinde asimetrik dimetilarginin (ADMA), nitrik oksid (NO), kreatin kinaz (KK) ve laktatdehidrogenaz (LDH) düzeyleri ölçüldü. Kalp ve böbrek dokularında reaktif oksidan oluşumu kemilüminesans yöntemi ile ölçüldü.Ayrıca oksidan hasar dokuların belirlenmesiiçin malondialdehit (MDA), glutatyon (GSH) düzeyleri ve $\mathrm{Na}+, \mathrm{K}+-$ ATPaz aktiviteleri ölçümleri yapıldı. İki böbrek tek klip uygulaması, KB'de artışa ve sol ventrikül fonksiyonlarında bozulmaya neden olurken plazma ADMA, KK ve LDH anlamlı olarak artmış bulundu $(p<0.05-0.001)$. Ayrıca hipertansiyon plazma NO düzeylerini ve doku GSH düzeyleri ile $\mathrm{Na}+, \mathrm{K}+-\mathrm{ATPaz}$ aktivitesini düşürürken MDA düzeyleri artmış bulundu ( $p<0.05-0.001)$. Diğer taraftan Nigella sativa uygulaması KB'yı anlamlı derecede düşürdü, oksidan hasarı azalttı ve sol ventrikül fonksiyonlarını düzeltti. Nigella sativa antioksidan ve antihipertansif etkileri ile hipertansiyonun neden olduğu renal ve kardiyak doku hasarına karşı koruyucu olmuştur. Bu bulgular Nigella sativanın RVH'da terapötik potansiyeli olabileceğini düşündürmektedir.

ANAHTAR SÖZCÜKLER: Antioksidan aktivite; hipertansiyon; oksidan hasar, Nigella sativa

\section{REFERENCES}

1. Textor SC, Lerman L. Renovascular hypertension and ischemic nephropathy.Am J Hypertens 2010; 23:1159-69.

2. Laursen JB, Rajagopalan $S$, Galis $Z$, Tarpey $M$, Freeman BA, Harrison DG.. Role of superoxide in angiotensin-IIinduced but not catecholamine-induced hypertension. Circulation 1997; 95:588-93.

3. Griendling KK, Minieri CA, Ollerenshaw JD, Alexander RW. Angiotensin II stimulates NADH and NADPH oxidase activity in cultured vascular smooth muscle cells. Circ Res 1994; 74:1141-8.

4. Minuz $P$, Patrignani $P$, Gaino S, Degan M, Menapace L, Tommasoli R, Seta F, Capone ML, Tacconelli S, Palatresi S, Bencini C, Del Vecchio C, Mansueto G, Arosio E, Santonastaso CL, Lechi A, Morganti A, Patrono C. Increased oxidative stress and platelet activation in patients with hypertension and renovascular disease. Circulation 2002; 106:2800-5.

5. Chong AY, Blann AD, Lip GY. Assessment of endothelial damage and dysfunction: observations in relation to heart failure. QJM 2003; 96:253-67.

6. Chade AR, Rodriguez-Porcel M, Herrmann J, Zhu X, Grande JP, Napoli C, Lerman A, Lerman LO. Antioxidant intervention blunts renal injury in experimental renovascular disease. J Am Soc Nephrol 2004; 15: 958-66.

7. Ali $\mathrm{BH}$, Blunden G. Pharmacological and toxicological properties of Nigella sativa. Phytother Res 2003; 17:299-305.

8. Badary OA, Taha RA, Gamal el-Din AM, Abdel-Wahab $\mathrm{MH}$. Thymoquinone is a potent superoxide anion scavenger. Drug Chem Toxicol 2003; 26:87-98.

9. Erşahin M, Toklu HZ, Akakin D, Yuksel M, Yeğen BC, Sener G. The effects of Nigella sativa against oxidative injury in a rat model of subarachnoid hemorrhage. Acta Neurochir (Wien) 2011; 153: 333-41.
10. Helle F Vågnes $\varnothing B$, Iversen BM. Angiotensin II-induced calcium signaling in the afferent arteriole from rats with two-kidney, one-clip hypertension. Am J Physiol Renal Physiol 2006; 291: F140-7.

11. Schiller NB Shah PM, Crawford M, DeMaria A, Devereux R, Feigenbaum H, Gutgesell H, Reichek N, Sahn D, Schnittger I, et al. Recommendations for quantitation of the left ventricle by two-dimensional echocardiography. American Society of Echocardiography Committee on Standards, Subcommittee on Quantitation of TwoDimensional Echocardiograms. J Am Soc Echocardiogr 1989; 2: 358-67.

12. Haklar G, Ulukaya-Durakbaşa $C$, Yüksel $M$, Daglı $T$, Yalcin AS. Oxygen radicals and nitric oxide in rat mesenteric ischemia-reperfusion: modulation by L-arginine and N-nitro-L-arginine methyl ester. Clin Exp Pharmacol Physiol 1998; 25:908-12.

13. Beuge JA, Aust SD. Microsomal lipid peroxidation. Meth Enzymol 1978; 52: 302-11.

14. Beutler E. Glutathione in red blood cell metabolism. A Manuel of Biochemical Methods. New York, Grune \& Stratton, 1975, pp.112-4.

15. Reading HW, Isbir T. The role of cation-activated ATPases in transmitter release from the rat iris. Q J Exp Physiol Cogn Med Sci 1980; 65:105-16.

16. Fiske $\mathrm{CH}$, Subbarow $\mathrm{Y}$. The colorimetric determination of phosphorus. J Biol Chem 1925; 66:375-400.

17. Lowry OH RN, Farr AL, Randall RJ. Protein Measurements with the folin phenol reagent. J Biol Chem 1951; 193:265-75.

18. Bai $Y$, Hui R. Dimethylarginine dimethylaminohydrolase (DDAH)--a critical regulator of hypertensive left ventricular hypertrophy? Med Hypotheses 2008; 70:962-6. 
19. Leiper J, Nandi M, Torondel B, Murray-Rust J, Malaki M, O'Hara B, Rossiter S, Anthony S, Madhani M, Selwood D, Smith C, Wojciak-Stothard B, Rudiger A, Stidwill R, McDonald NQ, Vallance P. Disruption of methylarginine metabolism impairs vascular homeostasis. Nat Med 2007; 13:198-203.

20. Rajagopalan $S$, Kurz S, Munzel T, Tarpey M, Freeman BA, Griendling KK, Harrison DG. Angiotensin II-mediated hypertension in the rat increases vascular superoxide production via membrane NADH/NADPH oxidase activation: contribution to alterations of vasomotor tone. J Clin Invest 1996; 97:1916-23.

21. Kako K, Kato M, Matsuoka T, Mustapha A. Depression of membrane-bound $\mathrm{Na}+-\mathrm{K}+-\mathrm{ATPase}$ activity induced by free radicals and by ischemia of kidney. Am J Physiol 1988; 254:C330-7.

22. Ross, D. Glutathione, free radicals and chemotherapeutic agents. Mechanisms of free-radical induced toxicity and glutathione-dependent protection. Pharmacol Ther 1988; 37:231-49.

23. Vaziri ND, Wang $X Q$, Oveisi $F$, Zhou $X J$. Induction of oxidative stress by glutathione depletion causes severe hypertension in normal rats. Hypertension 2000; 36:142-6.

24. Erşahin M, Sehirli $O$, Toklu HZ, Süleymanoglu S, Emekli-Alturfan E, Yarat A, Tatlidede E, Yeğen BC, Sener G. Melatonin improves cardiovascular function and ameliorates renal, cardiac and cerebral damage in rats with renovascular hypertension. J Pineal Res 2009; 47:97-106.
25. Mansour SM, Bahgat AK, El-Khatib AS, Khayyal MT. Ginkgo biloba extract (EGb 761) normalizes hypertension in $2 \mathrm{~K}, 1 \mathrm{C}$ hypertensive rats: Role of antioxidant mechanisms, ACE inhibiting activity and improvement of endothelial dysfunction. Phytomedicine. 2011; 18:641-7.

26. Abdelmeguid NE, Fakhoury R, Kamal SM, Al Wafai RJ. Effects of Nigella sativa and thymoquinone on biochemical and subcellular changes in pancreatic $\beta$-cells of streptozotocin-induced diabetic rats. J Diabetes 2010; 2:256-66.

27. El-Abhar HS, Abdallah DM, Saleh S. Gastroprotective activity of Nigella sativa oil and its constituent, thymoquinone, against gastric mucosal injury induced by ischaemia/reperfusion in rats. J Ethnopharmacol 2003; 84:251-8.

28. Badary OA, Abdel-Naim AB, Abdel-Wahab MH, Hamada FM. The influence of thymoquinone on doxorubicininduced hyperlipidemic nephropathy in rats. Toxicology 2000; 143:219-26.

29. Khattab MM, Nagi MN. Thymoquinone supplementation attenuates hypertension and renal damage in nitric oxide deficient hypertensive rats. Phytother Res 2007; 21:410-4.

30. Ismail M, Al-Naqeep G, Chan KW. Nigella sativa thymoquinone-rich fraction greatly improves plasma antioxidant capacity and expression of antioxidant genes in hypercholesterolemic rats. Free Radic Biol Med 2010; 48:664-72.

31. Gradman AH, Alfayoumi F. From left ventricular hypertrophy to congestive heart failure: management of hypertensive heart disease. Prog Cardiovasc Dis 2006; 48: 326-41. 